\title{
Inflorescence and Flower Development in the Hedychieae (Zingiberaceae): Scaphochlamys kunstleri (Baker) Holttum
}

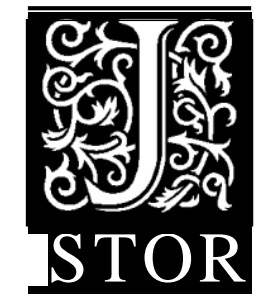

\author{
Bruce K. Kirchoff \\ Sciences 159: 261-274. \\ Made available courtesy University of Chicago Press: \\ http://www.journals.uchicago.edu/toc/ijps/1998/159/2
}

International Journal of Plant Sciences, Volume 159, Issue 2 (Mar., 1998), 261-274.

Kirchoff, B. K. 1998. Inflorescence and flower development in the Hedychieae

(Zingiberaceae): Scaphochlamys kunstleri (Baker) Holttum. International Journal of the Plant

Your use of the JSTOR archive indicates your acceptance of JSTOR' s Terms and Conditions of Use, available at http://www.jstor.org/about/terms.html. JSTOR' s Terms and Conditions of Use provides, in part, that unless you have obtained prior permission, you may not download an entire issue of a journal or multiple copies of articles, and you may use content in the JSTOR archive only for your personal, non-commercial use.

Each copy of any part of a JSTOR transmission must contain the same copyright notice that appears on the screen or printed page of such transmission.

International Journal of Plant Sciences is published by University of Chicago Press. Please contact the publisher for further permissions regarding the use of this work. Publisher contact information may be obtained at http://www.jstor.org/journals/ucpress.html.

International Journal of Plant Sciences

(C)1998 University of Chicago Press

JSTOR and the JSTOR logo are trademarks of JSTOR, and are Registered in the U.S. Patent and Trademark

Office. For more information on JSTOR contact jstor-info@ umich.edu.

C2001 JSTOR

http://www.jstor.org/ 


\title{
INFLRESCENCEANDFLOWERDEVELOPMENINTHEHEDYCHIEAE(ZINGIBERACEAE) SCAPHOCHLAMSKUNSTER(BAKER)HOLTIUM
}

\author{
Bruce K. Kirchoff \\ Department of Biology, P.O. Box 26174, University of North Carolina at Greensboro, Greensboro, North Carolina 27402 -6174, U.S.A.
}

\begin{abstract}
Primary inflorescence bracts are initiated in a spiral phyllotactic pattern on the flanks of the inflorescence apex. A cincinnus primordium forms in the axil of each primary bract. A prophyll is initiated in the transverse plane and later extends around the periphery of the cincinnus to produce a sheathing, but not tubular, bract. The apex of the cincinnus forms a flower. Flower development begins with the enlargement and flattening of the floral apex. Sepal initiation is sequential but differs in the first two flowers of a cincinnus. The different sequences are likely the result of developmental constraints that operate at the time of sepal initiation. After initiation, the margins of the sepals become confluent and intercalary growth produces the synsepalous calyx. The periphery of the flower, interior to the sepals, now rises to form a ring primordium composed of three common petallandroecial primordia. The common primordia enlarge, flatten, and separate to produce a petal to the exterior and an androecial member to the interior. The outer androecium forms in the regions of the ring primordium left vacant by the formation of the other floral parts. The anterior outer androecial member soon ceases growth and contributes only initially to the formation of the labellum. The gynoecium shows heterochrony in its time of initiation, which occurs much earlier than in other species of Zingiberaceae. Gynoecial initiation takes place on the margins of the central flora cup, at the time of the separation of the common primordia. Three gynoecial primordia from in antipetalous positions. Septa development differs in the basal and apical portions of the ovary. At the base, the primordia grow inward and fuse to form the central axis of the ovary. At the apex, there is little radial growth of the primordia. They cease growth soon after initiation and produce a unilocular cavity. Ovules form at the junction of these two regions and project up into the cavity. Epigynous nectaries form after all other floral organs.
\end{abstract}

\section{Introduction}

Inflorescence and flower development in the Zingiberaceae are important for several reasons. First, the Zingiberaceae possess structurally and developmentally complex flowers (Schumann 1904; Endress 1994; Kirchoff 1997). This complexity is noteworthy because flower structure has been a primary character for delimitation of the family and its division into four tribes (Holttum 1950; Smith 1981). The Zingiberaceae are characterized by flowers with strongly modified androecia in which four androecial members are represented by petaloid staminodes, one is missing, and one is polleniferous. On the basis of flower structure alone, the family can be separated from the closely related Costaceae by the lack of one androecial member and the fusion patterns that unite the remaining members of the androecium. In the Costaceae that have been studied, all five petaloid androecial members are united into a single petaloid labellum (Troll 1928; Kirchoff 1988b). In the tribes of the Zingiberaceae, four petaloid androecial members are united in lineage specific ways, whereas the fifth does not complete development. In the tribe Hedychieae, the subject of this article, two androecial members are united to form a (frequently) bibbed labellum, whereas the lateral (petaloid) staminodes remain free from the labellum above the floral tube. The Globbeae also have a bilobed labellum and free petaloid lateral staminodes. In the Zingibereae the lateral staminodes are fused to the labellum to produce a trilobed organ, and in the Alpineae the lateral staminodes are very small, never Manuscript received June 1997; revised manuscript received October 1997. petaloid, and are sometimes absent altogether (Holttum 1950; Smith 1981).

The structure of the gynoecium is also variable in the Zingiberaceae. Smith (1981) summarizes the morphology of the ovary by tribe and, in so doing, demonstrates that this character is of little taxonomic use. The Hedychieae have a trilocular ovary with axial placentae, or a unilocular ovary with basal or free columnar placentation. The ovaries of the Globbeae are unilocular with parietal placentation. Those of the Zingibereae are trilocular with axial placentation, and in the Alpineae the ovary is trilocular with axial placentation (sometimes imperfectly trilocular) or, rarely, unilocular with parietal placentation.

How can we explain this diversity in ovary structure? Is there a common plan that unites ovary structure of the family? Because of the "unilocular" nature of its ovary, Scaphochlamys is an important genus to study in this regard. The developmental study presented here is an initial contribution to understanding the structure of the ovary in the family.

The second reason for studying the Zingiberaceae is their potential role as subjects for the study of the evolution of developmental processes. The complexity of the flowers and their structural variability make the Zingiberaceae excellent subjects for this type of study. The richness of the organogenic stages of developmental suggest that it will be possible to find differences in the timing or morphology of developmental events between taxa. The nature of these differences might help to explain the evolution of flower structure in the family. If development proceeds from the general to the specific (von Baer 1828), we should expect a close relationship between development and taxon- 


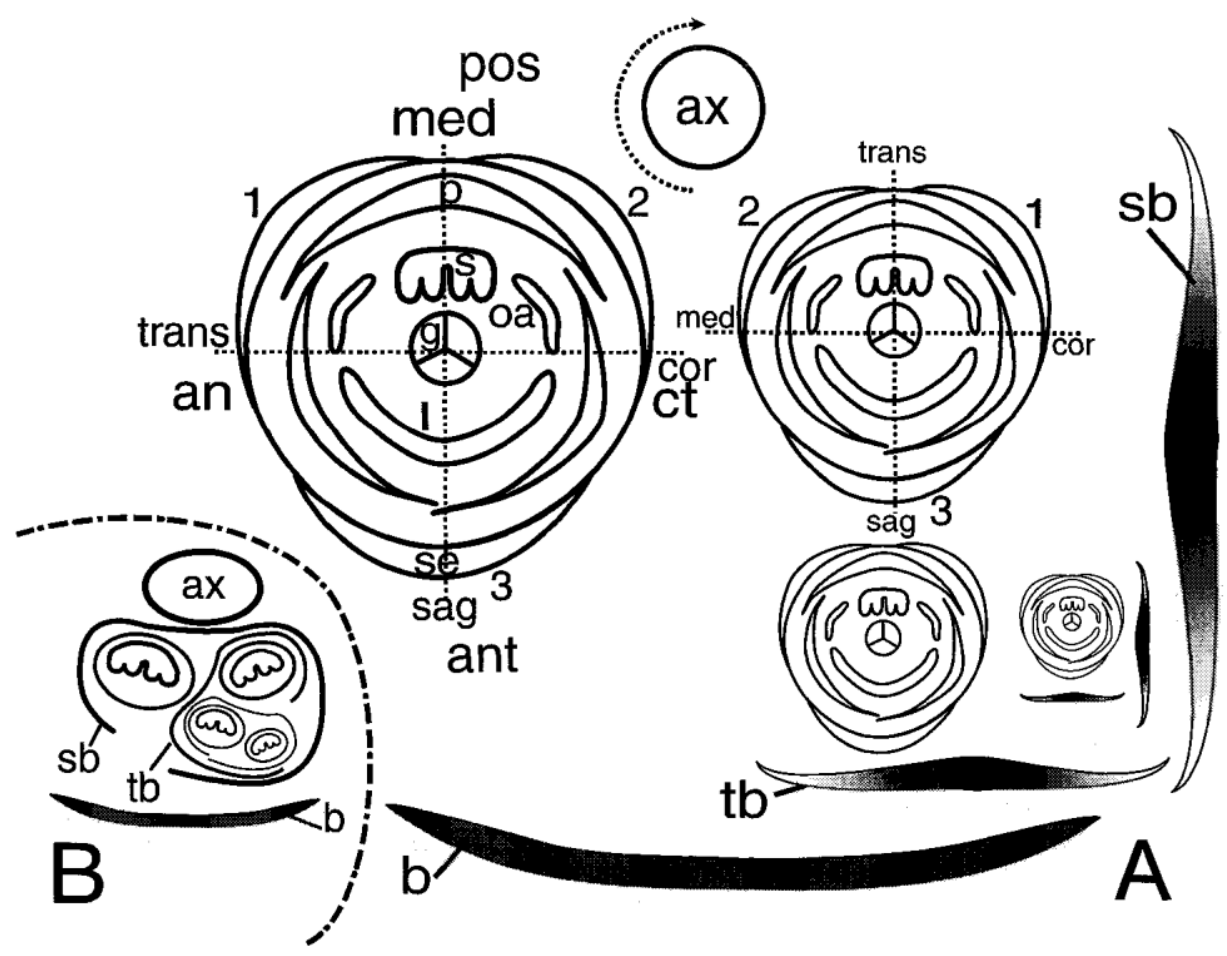

Fig. 1 Diagrams of cincinnus and flower structure in Scaphochlamys kunstleri. The flowers are formed successively as the cincinnus develops. Younger flowers are represented by smaller diagrams. Note that the flowers are all orientated with the stamen backing on the main florescence axis $(a x) . A$, Prophyll insertion and flower structure. $B$, Orientation of bracts and flowers at maturity. 1, 2, 3, Sequentially formed sepals. $a n=$ anodic side of flower; $a n t=$ anterior side of flower; dotted arrow $=$ direction of rise of the phyllotactic helix; $b=$ primary (main) bract; $c o r=$ coronal plane; $c t=$ cathodic side of flower; $g=$ gynoecium; $l=$ labellum; $m e d=$ median plane; $o a=$ outer androecial member (lateral petaloid staminode); $p=$ petal; pos = posterior side of flower; $s=$ stamen; $s a g=$ sagittal plane; $s b=$ secondary bract; $s e$ $=$ sepal; $t b=$ tertiary bract; trans $=$ transverse plane.

omy (Tucker 1984). Characters from early development should be most similar within a genus and less similar in other genera. If we find little or no relation between development and taxonomy, we may have a case of pure developmental variation, not correlated with taxonomy. This type of variation has been reported infrequently in the literature. Previous work on floral development in Hedychium (Kirchoff 1997) provides the basis for these types of comparisons.

Finally, the Zingiberaceae are an excellent family in which to study the nature of developmental constraints and their effects on morphological evolution. In at least two genera of the Hedychieae (Hedychium, Scaphochlamys) the even numbered flowers in the cincinni have an unusual orientation with respect to the inflorescence axis (fig. 1) (Eichler 1875; Kunze 1985; Kirchoff 1997). These flowers are oriented so that the single stamen backs on the main inflorescence axis instead of on the lower order axis of the cincinnus, as is more usual (fig. 2). This unusual orientation raises questions about the relationship between development and mature flower orientation. Are there constraints on the development of the even numbered flowers that might help explain their unusual orientation?

To address some of these questions, this article presents the structure and development of the inflorescence and flowers of Scaphochlamys kunstleri (Baker) Holttum. My purposes are to (1) enlarge our knowl edge of the pattern(s) of flower development in the Hedychieae by investigating flower development in a genus that is not closely related to those previously studied (Schachner 1924; Kirchoff 1997); (2) determine the developmental and structural relationships between the ovaries of S. kunstleri and those of $\mathrm{He}$ dychium (Kirchoff 1997); (3) search for differences in the timing of developmental events (heterochrony) during the organogenetic stages of flower development; and (4) develop a fuller understanding of flower orientation and its development in the Hedychieae.

\section{Material andMethods}

Young inflorescence buds of Scaphochlamys kunstleri (Baker) Holttum were collected from plants growing in the greenhouses of Fairchild Tropical Garden, Miami, Fla. (accession number FTG 83-266), and the University of North Carolina at Greensboro. The material in both greenhouses originated from the Royal Botanic Garden, Edinburgh (accession number 643232). A voucher is deposited at FTG (Kirchoff 84-23).

I studied flower and inflorescence development, using the epi-illumination, light microscopy technique developed by Sattler (1968) and later modified by Posluszny et. al (1980) and Charlton et. al (1989). I fixed living buds in formalinacetic acid-alcohol (FAA) (Berlyn and Miksche 1976), dehydrated them to $100 \% \mathrm{EtOH}$ and stained for several days in fast green (Johansen 1940). I destained with $100 \% \mathrm{EtOH}$ for a period of $2 \mathrm{~d}$ to several weeks. Photographs for study 


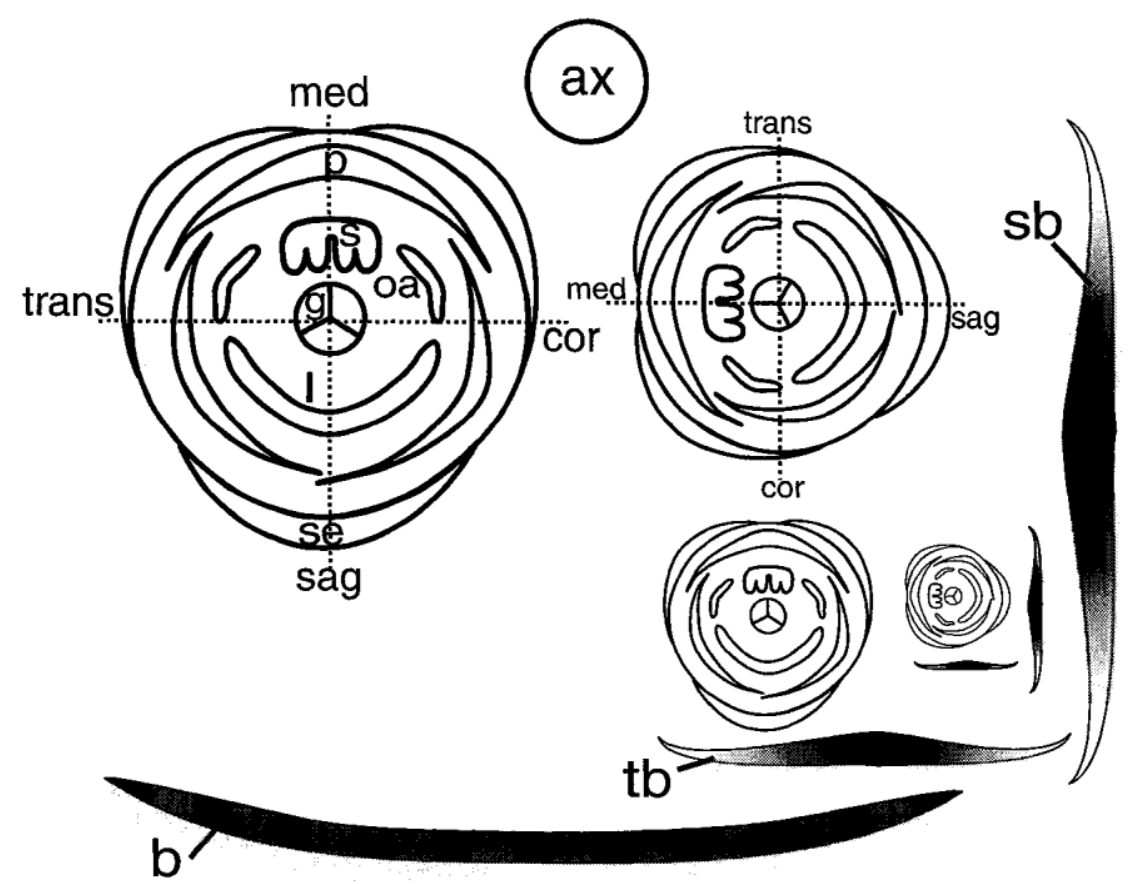

Fig. 2 Structure of a typical cincinnus. The flowers are formed successively as the cincinnus develops. Younger flowers are represented by smaller diagrams. Unlike Scaphochlamys, all flowers are oriented so that their median planes bisect the axes that bear them, not the main florescence axis. $a x=$ inflorescence axis; $b=$ primary (main) bract; $c o r=$ coronal plane; $g=$ gynoecium; $l=1$ labellum; med $=$ median plane of flower; $o a=$ outer androecial member; $p=$ petal; $s=$ stamen; $s a g=$ sagittal plane of flower; $s b=$ secondary bract; $s e=$ sepal; $t b=$ tertiary bract; trans $=$ transverse plane.

and publication were taken on Kodak technical pan film with a Leitz Ortholux 2 photomicroscope equipped with an Ultropak illuminator. I regulated the exposure time by varying the film speed set at the camera between ISO 300 and 400. The film was developed in Dektol for $3 \mathrm{~min}$ at $68^{\circ} \mathrm{C}$ with constant agitation to give maximum contrast (Kodak 1983).

In preparation for sectioning, some of the buds were pretreated with ethylenediamine for $2 \mathrm{~d}$ (Carlquist 1982), in an attempt to remove the hardening effects of long storage in fixative. I found little benefit to this procedure. All buds were washed in tertiary butyl alcohol (TBA) or EtOH to remove the fixative, dehydrated through a TBA series or with 2,2-dimethoxypropane, and prepared for standard paraffin technique (Berlyn and Miksche 1976). Sections were cut on a Reichert-Jung 2040 Autocut microtome at 4-5 pm and were mounted on slides using Bissing's modified Haupt's adhesive (Bissing 1974). Paraffin was removed using ClearRite III in place of xylene. Tannic acid and ferric chloride were followed by safranin and fast green in staining the sections (Berlyn and Miksche 1976). Permount was the final mounting medium. I photographed the sections with Kodak technical pan film on a Leitz Ortholux 2 photomicroscope. Exposure time was regulated by varying the film speed set at the camera between ISO 150 and 250. Kodak HC- 110 dilution $\mathrm{B}$ was used for $8 \mathrm{~min}$ at $68^{\circ} \mathrm{C}$ to develop the film (Kodak 1983).

Additional buds were embedded and sectioned in JB-4 Plus following washing and dehydration in EtOH and prestaining in fast green (Johansen 1940). Sectioning was carried out at 2.5-4 mm on a Reichert-Jung 2040 Autocut microtome (Berlyn and Miksche 1976). I did not stain the sections or coverslip the slides but observed them directly after mounting.

\section{Terminology}

The typological terminology of Troll (1964) and Weberling (1989) is useful in describing inflorescence structure in the Zingiberales. Where appropriate, I follow Kunze (1986) in modifying this terminology to fit these plants.

According to Troll's (1964) typological system, an inflorescence is a shoot system modified to serve the formation of flowers. Thus, "inflorescence" is a general term applied to any arrangement of flowers. A florescence is a terminal, indeterminate, flowering unit of an inflorescence. A main florescence terminates the main axis of the plant, whereas a coflorescence terminates a lateral axis. The florescences of the Zingiberaceae are composed of a central axis that bears lateral bracts. Each bract subtends an axillary branch called a "partial florescence." The partial florescences of the Zingiberaceae are cincinni. Since each florescence bears many flowers, it is a polytelic (many flowered) axis. A system of florescences aggregated into an inflorescence is called a "synflorescence." Thus, a polytelic synflorescence is an indeterminate inflorescence consisting of main and coflorescences, the coflorescences often arranged in branching units that repeat the structure of the inflorescence as a whole (paracladia).

In addition to the typological terminology described above, descriptive terminology can also be applied to inflorescence structure. A thyrse is an inflorescence with a single main axis and cymose lateral branches.

The branches of an inflorescence are numbered according to their position within the ramification. The primary (or first-order) axis bears the foliage leaves and terminates in an inflorescence. The bracts born directly on this axis are the 
axils of the primary bracts and terminate in primary flowers, the first flowers of the cincinni. Secondary bracts are born on these same axes (fig. IA, .O) and subtend secondary flowers, the second flowers of the cincinni. This numbering scheme is continued to tertiary and higher order bracts and flowers of the cincinnus.

Since the secondary, tertiary, and subsequent bracts arc the first phyllomes on each branch, they are also prophylls (the first phyllome on a branch system). I will use the term "prophyll" to refer to a bract when its position within the ramification is not essential to the point under discussion. I term the apex that arises in the axil of a prophyll a "cincinnus apex" because it continues the growth of the cincinnus by producing a prophyll and terminal flower.

The terms "median" and "transverse" specify the orientation of the flowers relative to the axes that bear them (Weberling 1989). The median plane bisects the flower and the axis that bears it (fig. IA, titer)). The transverse plane bisects the flower at right angles to the median plane (fig. IA, tams). Organs that lie in or close to the median plane are termed medial, and those in the transverse plane arc transversal. In most inflorescences these planes will always have the same relationship to the internal parts of the flower, no matter where the flower lies in the inflorescence. If the median plane of the first flower bisects a specific anther of the flower, the median planes of all other flowers will bisect the corresponding anthers in these flowers (fig. 2). This is not true in Scaphochlamys. In Scaphochlamys the median plane of each odd numbered flower bisects the anther of this flower, whereas the median planes of each even numbered flower run between the staminodes and the labellum of this flower (fig. 1A). This is because the flowers of Scaphochlamys are initiated and borne so that the single anther backs on the main inflorescence axis, not on the cincinnus axis that bears the flower (fig. I). Application of the terms median and transverse requires identifying this anther as medial in some flowers and transversal in others. To avoid this problem, I will use the term "sagittal" for the plane that bisects the stamen (fig. 1, sag) and "coronal" for the plane that. separates the staminodes from the labellum (fig. 1, car). I will use these terms no matter what the orientation of the flowers with respect to the axis that bears them. The terms sagittal and coronal are appropriate because they are defined with reference to the internal form of the organ(ism), not to the attachment of this organ(ism) to sonic external structure. The (mid-) sagittal plane is a vertical plane through the body of a bilaterally symmetrical organism, separating the body into right and left halves. In humans, the coronal plane is the plane that runs through the corona! suture and separates the frontal and parietal lobes of the brain.

In this article I treat the posterior side of the flower as the sidle that backs on the main florescence axis (fig. IA, pas). The anterior side is the side away from this axis (fig. IA, ant). Unless otherwise noted, the anterior sidle of the flower is always at the bottom of the photographs in polar views of floral buds and in cross sections. The abaxial sidle of the flower is the sidle away from the lower order axis that bears the flower, and the adaxial side is adjacent to this axis.

The anodic side of the flower is the transverse side that lies in the direction of the rise of the phyllotactic helix (fig. 1, an). The cathodic sidle lies opposite the direction of phyllotactic rise (fig. 1, ct). The terms "anodic" and "cathodic" are applicable only to the first flower of the cincinnus. Although cincinni of both handedness occur, the secondary bract is always shown to the right in diagrams and polar views.

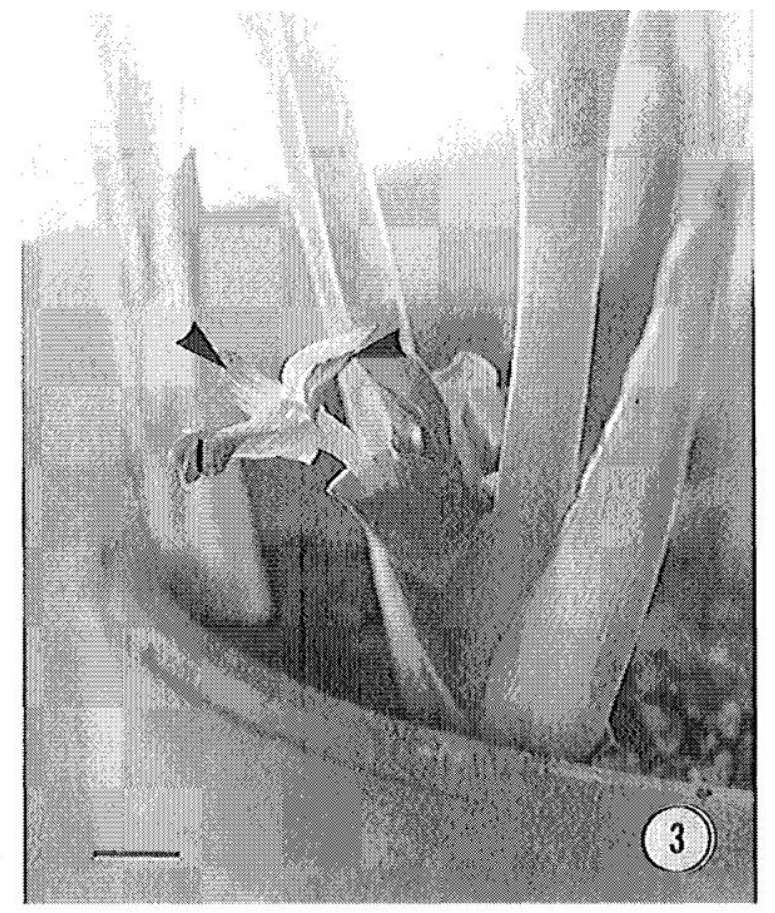

Fig. 3 Inflorescence position and flower structure in Scaphochlamys. arrows $=$ outer androecial member (lateral staminode); $l$ $=$ labellum. Scale bar $=10 \mathrm{~mm}$.

\section{Results \\ Organography}

Scaphochlamys kunstleri (Baker) HoRt. is a small plant with shoots to ea, $20 \mathrm{~cm}$, distichous leaves, and a terminal inflorescence (fig. 3). Each aerial shoot bears two to three bladeless cataphylls and two to three foliage leaves before terminating in an inflorescence. The foliage leaves are divided into an open sheath, indistinct petiole, and a blade. The inflorescence consists of a single terminal (main) florescence. Coflorescences do not occur in the genus. The primary (main) bracts of the inflorescence are spirally arranged and subtend partial florescences composed of cincinni. The inflorescence of Scaphochlamys is, thus, a thyrse. In typological terminology, the inflorescence of the Zingiberaceae is a polytelic synflorescence whose florescence system is usually represented by a single main florescence (Kunze 1985). The inflorescences I investigated formed approximately five fertile bracts before abortion of the apex. Each cincinnus bears from two to six flowers, each enclosed in a prophyll that at least partially surrounds the flower and the remainder of the cincinnus (fig. 113). The prophylls are open to their base. At maturity, the overlapping edges of the secondary bract (the first prophyll of a cincinnus) face the primary bract, giving the false impression that this prophyll is inserted on the adaxial side of the cincinnus (fig. 111). The developmental study presented in this article shows that this bract is initiated (and therefore inserted) laterally (fig. IA).

Within a cincinnus, the flowers are most commonly 
arranged so that the single anther backs on the inflorescence axis (fig. 1). At maturity, the flowers retain this orientation but undergo a slight rotation so that the sagittal planes of the flowers are no longer parallel but converge on the center of the inflorescence (fig. 1B). In a survey of 10 cincinni from two inflorescences, I found that in nine the sagittal planes of the flowers all converged on the florescence axis (fig. 1B), while in one the second flower backed on the lower order axis, as is more common for cincinni (fig. 2).

The flowers of Scaphochlamys have a construction similar to those found in other members of the Hedychieae (Zingiberaceae). The floral organs are arranged in whorls of three with "fusions" among and between whorls to produce a floral tube and staminodial labellum. The perianth is differentiated into a synsepalous calyx, which is free from the other floral members above the ovary, and a petaloid corolla that is united with the androecial members to form the floral tube. Of the three petaloid floral members interior to the petals, the labellum lies in the sagittal plane, is bilobed, and is larger than the others (figs. 1 A; 3,1). The lateral staminodes are inserted closer to the coronal plane and are unlobed (figs. 1A, 3).

The ovary is inferior, unilocular above and trilocular below. There are four to eight ovules per ovary. The ovules are inserted on axile placentas near the junction of the trilocular and unilocular portions of the ovary. Unlike other members of the Zingiberales, the apical closure of the locules is not extended into a prolongation. Epigynous nectaries are inserted on top of the ovary, at the base of the style.

\section{Inflorescence and Cincinnus Development}

Primary bracts of the inflorescence are initiated on the flanks of the inflorescence apex in a spiral phyllotactic pattern. As the inflorescence ages, the inflorescence apex decreases in size and finally ceases growth with the production of a terminal sterile stub (fig. 4). The size of the apex relative to the bracts decreases at the time of apex abortion.

A cincinnus primordium is formed in the axil of each primary bract. Following initiation, a young cincinnus widens and produces a transversely elongated primordium. The primordium becomes more pointed on one side and initiates a prophyll, the secondary bract, in the transverse plane (fig. 5,sb). The lateral portions of the open sheath are formed later (fig. 1B).

The secondary bract may be formed on either the anodic or cathodic side of the cincinnus apex. That is, the cincinni may be either right or left handed. An axillary bud forms in the axil of the secondary bract and continues the growth of the cincinnus, whereas the apex of the first-order axis produces a flower (fig. 6).

Continued growth of the cincinnus occurs in a similar manner. A cincinnus apex forms in the axil of the prophyll borne on the lower order axis (fig. 6). This apex produces a new prophyll and terminates in a flower. The next cincinnus apex forms in the axil of the new prophyll and continues the growth of the cincinnus.

\section{Flower Development}

The following description applies most completely to the first flower of a cincinnus. As far as possible, I verified this developmental sequence with the second and third flowers of cincinni but lacked sufficient material for a complete developmental study of these flowers. In the following description, the directional terms apply only to the odd-numbered flowers. The orientation of the even-numbered flowers requires different terms to describe the spatial relations of the parts of these flowers during development (fig. 1).

Development of the first flower of a cincinnus begins with the transformation of the cincinnus apex into a floral primordium (fig. 6). The primordium enlarges, flattens apically, and assumes a rounded, obdeltoid appearance in polar view (fig.7). The rounded corners of the primordium are the sites of sepal initiation (fig. 7, arrows). Sepals are initiated sequentially, beginning with the sepal farthest from the secondary bract (figs. 1, 7-8). The second sepal forms adjacent to the secondary bract, in a posterior position (fig. 8). The third sepal forms anteriorly (fig. 8). Following a short period of growth, the sepals extend their insertion sites around the periphery of the flower until the margins of adjacent sepals become confluent (figs. 8-13). Intercalary growth below the sepals produces the majority of the synsepalous calyx.

One difference between the development of the first and second flowers is the sequence of sepal initiation. The sequence of initiation in the second flower is a mirror image of the sequence in the first (fig. 1). The first sepal is initiated as far as possible from the tertiary bract and the florescence axis. This places it adjacent to the secondary bract (fig. 1). The second sepal is initiated adjacent to the first flower, in a posterior position. The third sepal is initiated anteriorly.

In the third flower, sepal initiation follows the same sequence as in the first flower. In this respect, the first and third flowers are symmetrical. I have no data on the development of the fourth and subsequent flowers.

During sepal initiation, the periphery of the floral primordium, interior to the sepals, enlarges to produce a raised ring primordium (figs. 8, 9). In its early stages, the ring primordium is nearly radially symmetrical. It is composed of three only slightly distinct common petal/androecial primordia united for most of their depth. These primordia surround a central depression, the floral cup, the site of gynoecial initiation (figs. 8, 9). From a early stage of its growth, the posterior common primordium (fig. 9, arrow) is slightly larger than the anterior primordia, which are approximately equal in size. Two structures, an androecial and a corolla member, will develop from each common primordium. The posterior primordium forms the polleniferous stamen and its associated petal.

As development proceeds, the common primordia enlarge, flatten, and become increasingly distinct (fig. 

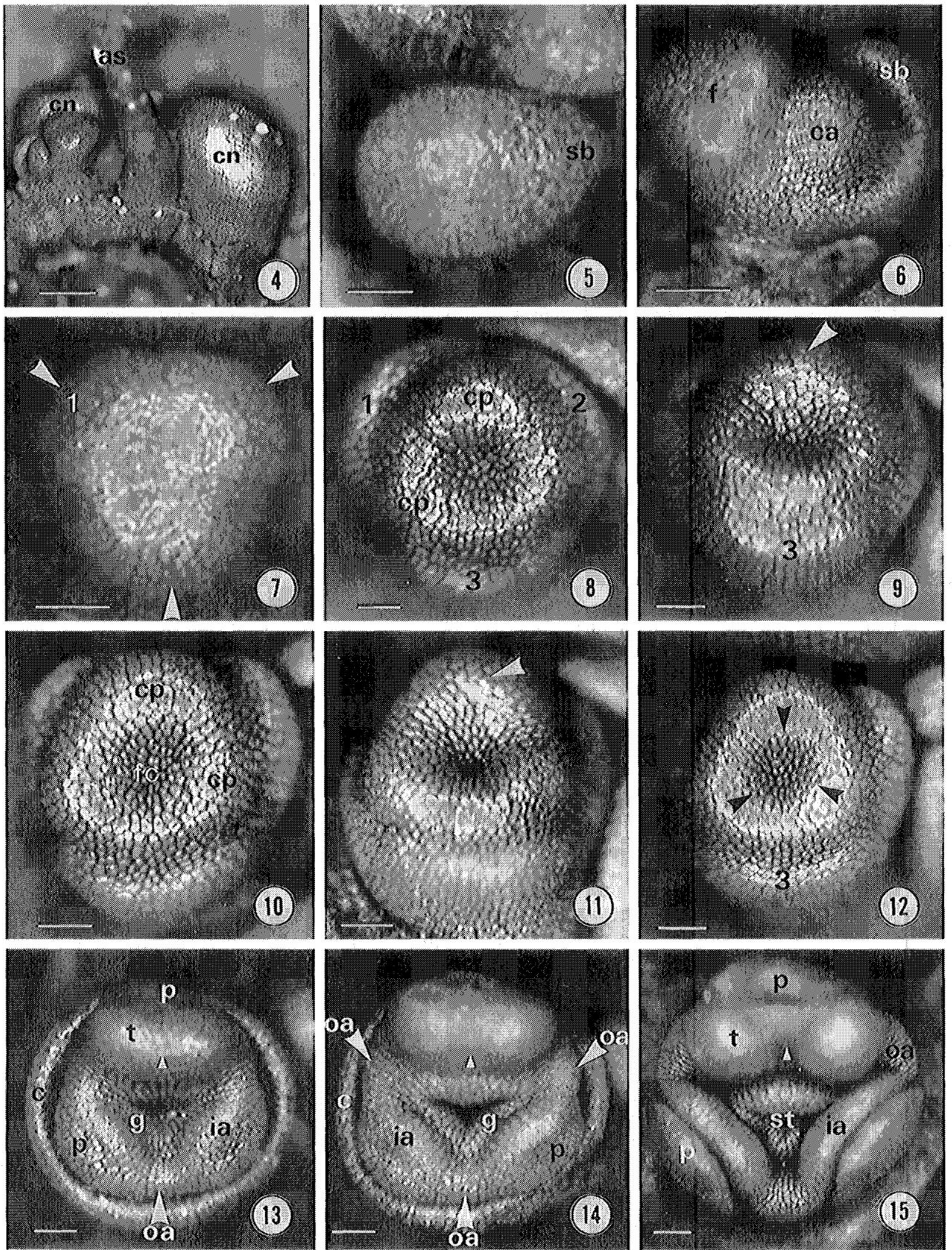

Figs. 4-15 Inflorescence and flower development. Fig. 4, Lateral view of aborted inflorescence apex forming sterile stub (as). $c n=$ cincinnus. Scale bar $=200 \mu \mathrm{m}$. Fig. 5 , Initiation of secondary bract $(\mathrm{sb})$ on young cincinnus. Scale bar $=50 \mu \mathrm{m}$. Fig. 6, Oblique view of cincimus with first flower $(f)$, secondary bract $(s b)$, and cincinnus apex $(c a)$. Scale bar $=50 \mu \mathrm{m}$. Fig. 7, Early sepal formation (arrows). $l$ $=$ first formed sepal. Scale bar $=50 \mu \mathrm{m}$. Iig. 8 , Sequence of sepal initiation and formation of ring primordium. $c p=$ common primordium. $1,2,3 \Rightarrow$ sequentially formed sepals. Scale bar $=50 \mu \mathrm{m}$. Fig. 9, Oblique view of ring primordium. Note that the posterior common 

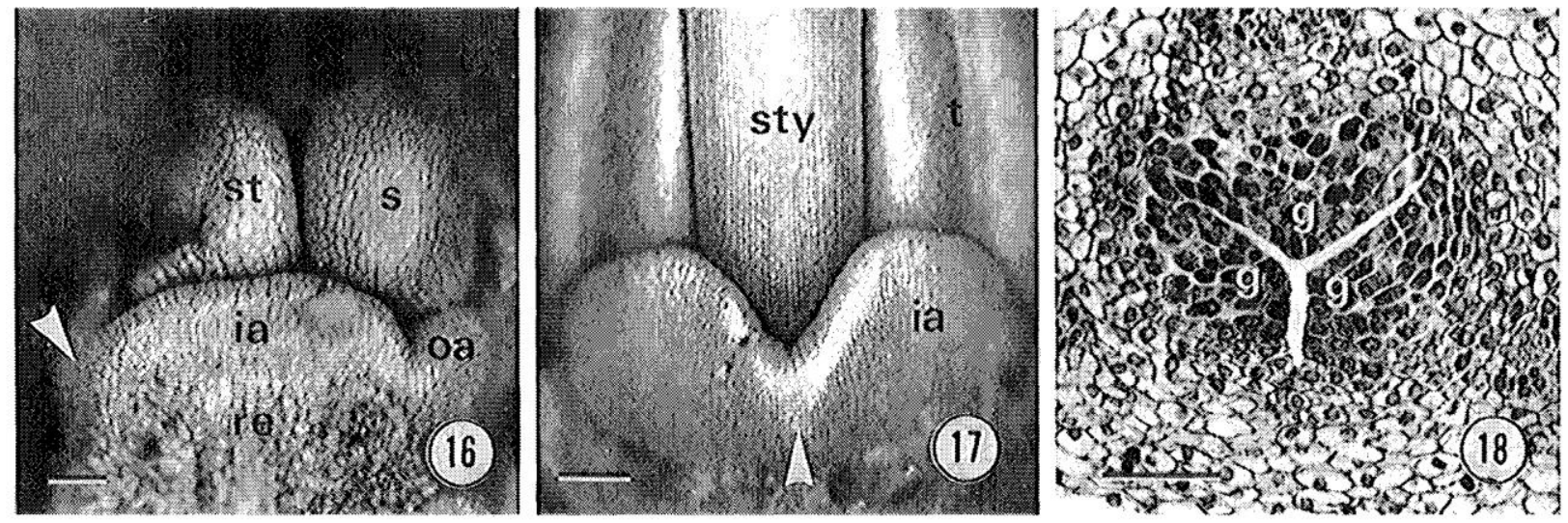

Figs. 16-18 Development of the outer androceium and gynoecium. lig. 16, Lateral view of same flower as in fig. 15. The anterior outer androecial member (arrow) has ceased growth. i $a=$ inner androccial member; $o a=$ outer androecial member; re $=-:$ removed petal; $s=$ stamen; $s t=$ stigma. Scale bar $=50 \mu \mathrm{m}$. lig. 17 , Lateral view of older flower with aborted anterior outer androecial member (arrow). ia $=3$ inner androecial member; $s t y=$ style; $t=$ thecac. Scale bar $=100 \mu \mathrm{m}$. Fig. 18, Cross section showing initiation of three gynoecial primordia $(g)$. Scale bar $=50 \mu \mathrm{m}$.

$10, \mathrm{cp})$. Early in this process, the posterior primordium is only slightly larger than the anterior (fig. 9). It soon becomes distinctly larger (fig. 11, arrow). Throughout these stages the ring primordium remains a raised, three-lobed ring of tissue inserted above the sepals (figs. 8-12).

Following enlargement, each common primordium divides to produce a petal, to the exterior, and an antipetalous androecial member, to the interior (fig. 13). The posterior inner androecial primordium forms the stamen, and the anterior primordia form two sections of the labellum. Separation of the three common primordia is nearly simultaneous but is decidedly unequal (fig. 13). The primordium of the posterior stamen is distinctly larger than its petal, whereas the anterior androecial primordia are only slightly larger than their associated petals (fig. 13).

The thecae form at an early stage of stamen development, soon after the separation of the common primordia (fig. 13,t). From the time of their appearance, the thecae are separated by a sterile connective that becomes increasingly distinct as the flower matures (figs. 13-15, small arrow).

Formation of the outer androecium takes place on the regions of the ring primordium left vacant by the formation of the other floral parts (figs. 13-14,oa). The anterior outer androecial member forms first, at about the same time as the separation of the common primordia (fig. 13,oa). The posterior outer androecial primordia are initiated slightly later and more or less si multaneously (fig. 14). By the stage of stigma formation, all three primordia are present and are approximately equal in size (fig. 15).

Soon after its initiation, the anterior outer androecial member ceases growth (figs. 16, 17, arrow). The two posterior outer androecial members continue growth and produce the lateral, petaloid staminodes (fig. 16,00 . Intercalary growth below the two anterior inner androecial members produces the majority of the labellum (fig. 17,ia).

Gynoecial initiation occurs before or at approximately the same time as the separation of the common primordia (fig. 12, arrows). It begins with the deepening of the floral cup, which results from upgrowth of the surrounding ring primordium (figs. 8, 10) followed by initiation of the gynoecial primordia on the interior surface of the cup (fig. 13). The three gynoecial primordia form in antipetalous positions, below the insertion of the common primordia (figs. 12, 13, 18, 19A). The gynoecia enlarge both acropetally and basipetally. Basipetally, they produce the septa (figs. 18, 19B). Acropetally, they produce the stigma and style (figs. 15, 19B), In forming the stigma, the posterior gynoecial primordium enlarges slightly more than the anterior to produce the larger posterior stigma lobe (figs. 14-16).

The development of the septa is slightly „different in the basal and apical portions of the ovary (fig. 19). In the basal region, the gynoecial primordia grow radially and fuse at the center of the ovary to form the septa

primordium (arrow) is larger than the anterior. $3=$ third formed sepal. Scale bar $=50 \mu \mathrm{m}$. Fig. 10, Distinct common primordia ( $c p$ ) surrounding floral cup $(f c)$. Scale bar $=50 \mu \mathrm{m}$. Fig. 11, Enlargement of posterior common primordium (arrow). Scale bar $x=50 \mu \mathrm{m}$. Fig. 12. Gynoecial initiation (arrows), $3=$ third formed sepal. Scalc bar $=50 \mathrm{pm}$. Fig. 13, Separation of common primordia to form petals ( $p$ ) and inner androecial members (ia). The separation of the posterior common primordium occurs before the separation of the anterior primordia. Small arrow $=$ comective of the fertile stamen; $c=$ synsepalous calyx; oa $=$ anterior outer androecial member; $g=$ gynoecial primordium; $t=$ theca. Scale bar $=50 \mu \mathrm{m}$. Fig. 14, Formation of outer androecium $(o a)$. Small arrow $=$ connective of the fertile stamen; $c=$ synsepalous calyx; $g=$ gynoecial primordium; $i a=$ inner androccial member; $p=$ petal. Scale bar $=50 \mu \mathrm{m}$. Fig. 15 . Style $(s t)$ formation. Small arrow $=$ connective of fertile stamen; $i a=$ inner androecial member; $o a=$ outer androecial member; $p=$ petal; $t=2$ theca. Scale bar $=50 \mu m$. 


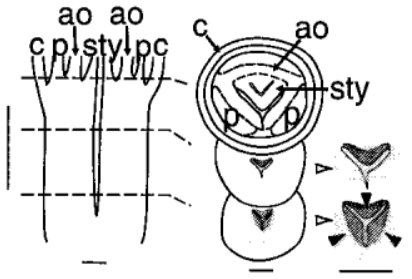

A

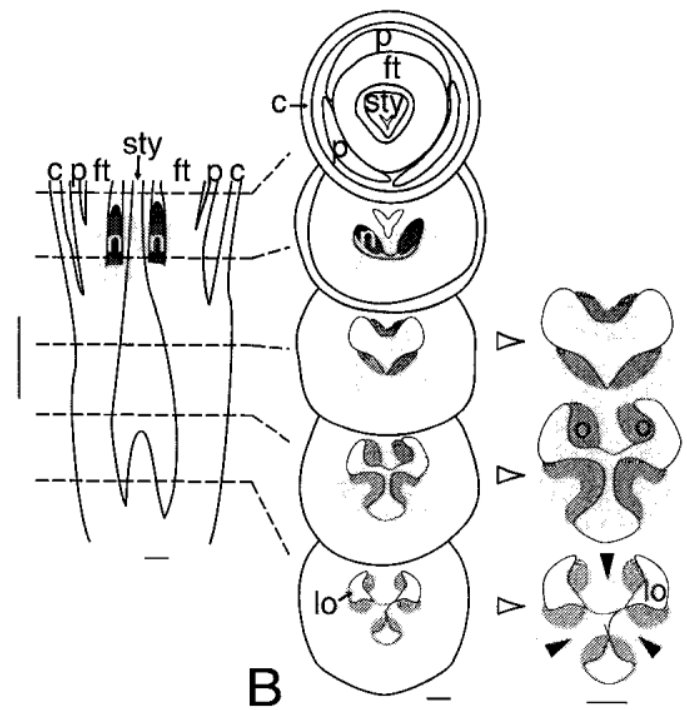

Fig. 19 Diagrams of gynoecial initiation. Longitudinal diagrams reconstructed from serial sections. Note that the vertical scales of the reconstructions are exaggerated. The shaded areas contain smaller, more densely cytoplasmic cells than do those in the surrounding regions. $A$, Shortly after formation of style (sty). B, Ovule $(o)$ initiation and closure of locules $(l o)$. Black arrows $=$ center of gynoecial primordia and septa; $a o=$ androecium; $c=$ sepal or synsepalous calyx; $f t=$ floral tube; $n=$ nectary; $p=$ petal. Scale bars $=100 \mu \mathrm{m}$.

and central axis of the ovary (fig. 19B, lowest section). In this region, the locules arise from the expansion of the cavities between gynoecial primordia (compare figs. 19A, B). By contrast, in the apical region of the ovary there is little radial growth of the septa. In this region the septa cease growth soon after initiation and produce a unilocular cavity (fig. 19B). At maturity, the ovules project up into this cavity giving the impression of a unilocular ovary. In the middle of the ovary the gynoecial primordia undergo an intermediate amount of radial growth. Incomplete septa are formed in this region (figs. 19B, 20).

The stigma and style continue to enlarge during formation of the septa. As they emerge from center of the flower, they are positioned on the anterior side of the stamen, between and in front of the thecae (fig. $21)$. As the stamen enlarges, the thecae gradually surround the style (fig. 17) until they completely enclose it at maturity.

As the gynoecium enlarges, placenta and ovules form at the junction of the unilocular and trilocular regions of the ovary (figs. 19B, 20, 22). Each incomplete septa produces one or two ovules (fig. 22). The ovules initiate integuments in basipetal order. The inner integument forms first, followed by the outer integument (fig. 22). Closer to maturity, an aril forms at the base of each ovule (fig. 23). The arils are composed of a basal ring of tissue apically divided into a series of equal projections.

The epigynous nectaries are the last floral organs to be formed. They are initiated from gynoecial tissue on the anterior side of the style (fig. 24). At maturity, they are inserted just in front of, and below, the attachment of the style.

\section{Discussion}

Inflorescence Structure and Development

The inflorescence of Scaphochlamys kunstleri is a simple thyrse, similar to that found in Hedychium and other members of the Hedychieae (Holttum 1950; Kirchoff 1997). Following Troll's (1964) typological system, this type of inflorescence is termed a polytelic synflorescence (Kunze 1985; Weberling 1989). In Scaphochlamys and other members of the Hedychieae, the elaborate branch systems of these polytelic synflorescence are reduced to a single main florescence (Kunze 1985).

The prophylls of S. kunstleri are open (split) to the base, as is common in the Hedychieae (Holttum 1950, p. 84). Prophylls that are tubular, at least at their base, are more common in subfamily Alpineae but also occur in Hedychium (Holttum 1950; Kirchoff 1997). On the basis of their similarity to the tubular bases of leaves, Holttum (1950, p. 8) suggests that tubular prophylls are the primitive state for the Zingiberaceae.

Early secondary bract development in S. kunstleri is similar to that in Hedychium gardnerianum and $\mathrm{H}$. coronarium described elsewhere (Kirchoff 1997). The secondary bracts are initiated in the transverse plane, on the side of the young cincinnus primordium. They later extend partially around the circumference of the cincinnus. In Hedychium, the portions of the bract that extend around the circumference of the cincinnus contribute to the tubular bases of the secondary bracts. Since S. kunstleri has nontubular (open) secondary bracts, the later developmental pattern of these bracts must differ from those of Hedychium. These later developmental stages were not investigated in this study.

The fact that the secondary bracts of both genera 

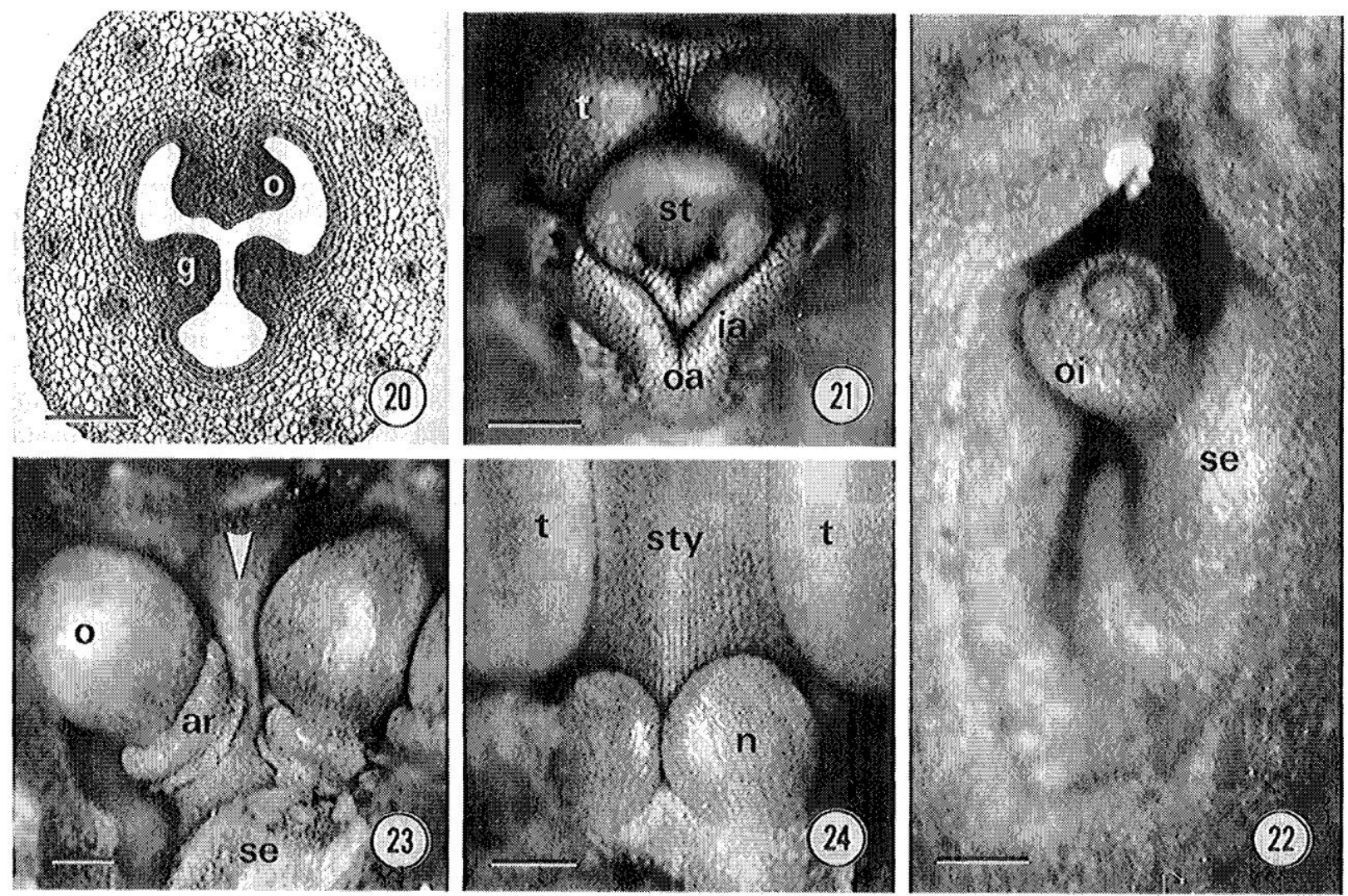

Figs. 20-24 Later stages of flower formation. Fig. 20, Cross section of ovary at ovule $(o)$ formation. The gynoccial primordia $(g)$ are enlarging to form the septa. Scale bar $=500 \mu \mathrm{m}$. Fig. 21, Enlargement of the stigma $(s t)$. ia $=$ imner androecial member; oa $=$ outer androecial member; $t=$ theca of anther. Scale bar $=100 \mu \mathrm{m}$. Fig. 22, Integument formation. Note the reduction in the size of the septa (se) above the insertion of the ovules. of $=$ outer integument. Seale bar $=100 \mu \mathrm{m}$. Fig. 23, Aril (ar) formation. Note the reduction in the septa (se, arrow) above the insertion of the ovules $(o)$. Scale bar $=200 \mu \mathrm{m}$. Fig. 24, Young cpigynous nectaries $(n)$ at the base of the style $(s t y)$. $t=$ theca. Scale bar $=100 \mu \mathrm{m}$.

are initiated on the side of the cincinnus and only later extend around the periphery indicates, contrary to

Minn (1950), that the tubular condition may be advanced. Tubular bracts may have arisen as a postinitiation modification of secondary bract development. This conjecture receives support from a study of secondary bract development in the Costaceae, the likely sister group of the Zingiberaceae (Dahlgren and Rasmussen 1983; Kirchoff 1988a; Kress 1990). In Cosms scaber, the secondary bract is initiated on the side of the cincinnus apex in a position similar to its site of initiation in Hedychium and Scaphochlamys (Kirchoff 19880. However, in Costus secondary bract initiation does not extend around the periphery of the cincinnus; instead, the secondary bract remains open at maturity. Thus, preliminary parsimony analysis indicates that the ancestor of the Costaceae and Zingiberaceae had open secondary bracts that were initiated on the side of the cincinnus. Further phylogenetic analysis and study of secondary bract development in the Zingiberaceae and Costaceae is necessary to support this interpretation.

In a normal cincinnus, all of the flowers arc initiated so that they back on the lower order axis that bears them (fig. 2) (Kunze 1985). Consequently, a single plane bisects the flower, the subtending prophyll and the lower order axis. In these cases, the terms "sagittal" and "medial" refer to the same plane, which is commonly referred to as the "median plane" (Weber- ling 1989). In contrast, in S. kunstleri and Hedychium the flowers are all initiated so that they back on the main florescence axis. As a consequence, the medial and sagittal planes coincide only in the odd-numbered flowers (fig. 1). In evennumbered flowers, the sagittal plane bisects the flower, the primary bract, and the main inflorescence axis, whereas the median plane bisects the prophyll and the axis that bears the flower (fig. 1) (Pichler 1875; Kunze 1985; Kirchoff 1997). These changes produce cincinni in which the odd- numbered flowers have their normal orientation, whereas the even-numbered flowers are oriented with their sagittal planes rotated $90^{\circ}$ relative to their position in normal cincinni (figs. 1, 2). This orientation of the flowers most likely plays some role in pollination, though no direct evidence has been collected to support this hypothesis.

One distinct difference between inflorescence development in Scaphochlamys kunstleri and Hedychium gardnerianum (Kirchoff 1997) is that in $H$. gardnerianum the margins of the primary bracts intrude be- 
tween the cincinni and the inflorescence soon after the formation of the cincinni. The bracts do not intrude in this way in S. kunstleri.

\section{Flower Structure}

\section{Labellum}

The labellum is the floral part that has received the most attention in the literature. The interpretation of the labellum supported by developmental work (Schachner 1924; Kirchoff 1997; present study) is that proposed by Lestiboudois (1829) and modified by Eichler (1884). Costerus (1915) also supports this interpretation, in part. According to this interpretation, the labellum consists of two members of the inner androecial whorl. The third member of the inner whorl is the fertile stamen. Developmental study supports this interpretation by demonstrating that the primordia of the two inner petaloid staminodes are joined by intercalary growth to produce the labellum. The outer androecial member initiated between these primordia ceases growth soon after initiation and contributes only initially to the formation of the labellum. The other two outer androecial members form the two lateral staminodes.

One caveat must be added to this interpretation. Costerus (1915) investigated the vascularization of the labellum in a number of genera (Burbidgea, Curcuma, Amomum, Hornstedtia, Hedychium, Kaempferia, Alpinia). He concluded that the labellum was composed of three androecial members: two from the inner androecial whorl and one outer androecial member. According to Costerus (1915), the outer androecial member is represented by the medial vein of the labellum. Although I have been unable to corroborate this hypothesis in Scaphochlamys or Hedychium (Kirchoff 1997), developmental study of other genera may validate this hypothesis in some cases.

The term "labellum" has also been applied to the flowers of the Lowiaceae, Cannaceae, and Costaceae. These uses are unfortunate, because the labellums of the Lowiaceae and Zingiberaceae are not homotopous and therefore are not homologous. The labellum of the Lowiaceae is a single enlarged petal, with no contribution from the androecium (Kirchoff and Kunze 1995). The labellums of the Cannaceae and Costaceae can, at best, be considered partially homologous (Klaauw 1966; Sattler 1984) to those of the Zingiberaceae. The labellum of the Cannaceae is formed from a single petaloid staminode of the inner whorl (Kirchoff 1983b; Kunze 1984). It is thus homotopous to one half of the labellum of the Zingiberaceae. The labellum of the Costaceae forms from intercalary growth below five androecial primordia, two from the inner whorl and three from the outer (Kirchoff 1988b). The intercalary growth unites the primordia and results in a structure that is typologically five parted (Troll 1928).

\section{Nectaries}

All of the families of the Zingiberales, except the Lowiaceae (Kirchoff and Kunze 1995), possess some type of nectary (Pai and Tilak 1965). In most cases, these are gynopleural nectaries (Smets and Cresens 1988). Gynopleural nectaries are nectaries that occur either in the septa of the locules, or in contiguous regions of the ovary. In the Zingiberales, gynopleural nectaries occur both in the septa (Strelitziaceae, Cannaceae, Marantaceae) and in regions contiguous with the septa but above (Musaceae) or below (Heliconiaceae) the locules. In the present context, the structure of the nectaries in the Cannaceae, Marantaceae, and Costaceae are particularly important. The Glade \{ Cannaceae, Marantaceae $\}$ is the sister group of the Glade \{Costaceae, Zingiberaceae (Kirchoff 1988a; Kress 1990, 1995). The Marantaceae and Cannaceae both possess typical gynopleural nectaries (Pai 1963; Tilak and Pai 1970). The Costaceae possess modified gynopleural nectaries that occur at the top of the ovary (Newman and Kirchoff 1992). The presence and position of these nectaries, as well as the phylogenetic relationships of the families, make it highly probable that the epigynous nectaries of the Zingiberaceae are derived from gynopleural nectaries. Brown (1938) first proposed this hypothesis, which was supported by the work of Rao et al. (1954), Rao and Pai (1959, 1960), and Rao and Gupte (1961) and is discussed in more detail by Rao (1963) and Newman and Kirchoff (1992). The developmental description presented in this article confirms the placement of the nectaries of the Zingiberaceae in an antero-lateral position, approximately above the septa. This placement further supports the hypothesis that the epigynous nectaries are derived from gynopleural nectaries. This article also confirms Holttum's (1950) statement that the nectaries arise relatively late in flower development.

\section{Ovary}

The mature form of the ovary differs among Scaphochlamys kunstleri, Hedychium gardnerianum, and $H$. coronarium. In Hedychium, the ovary is trilocular with axial placentas that bear numerous ovules. In S. kunstleri, the ovary is basally trilocular and apically unilocular. The four to eight ovules are inserted on axial placentas at the junction of the tri- and unilocular portions of the ovary. Developmental study confirms this insertion point and the close relationship between the structure of the ovaries in these genera. Gynoecial initiation in S. kunstleri is similar to that of $H$. gardnerianum and H. coronarium (Kirchoff 1997). In all three species, the gynoecium is formed from three antipetalous gynoecial primordia, which enlarge and fuse at the center of the flower to form the ovary axis and placentas. In Hedychium this growth and fusion occurs throughout the length of the ovary, whereas in $S$. kunstleri it only occurs in the basal (trilocular) regions. These developmental similarities support the interpretation of the ovary of S. kunstleri as trilocular. They 


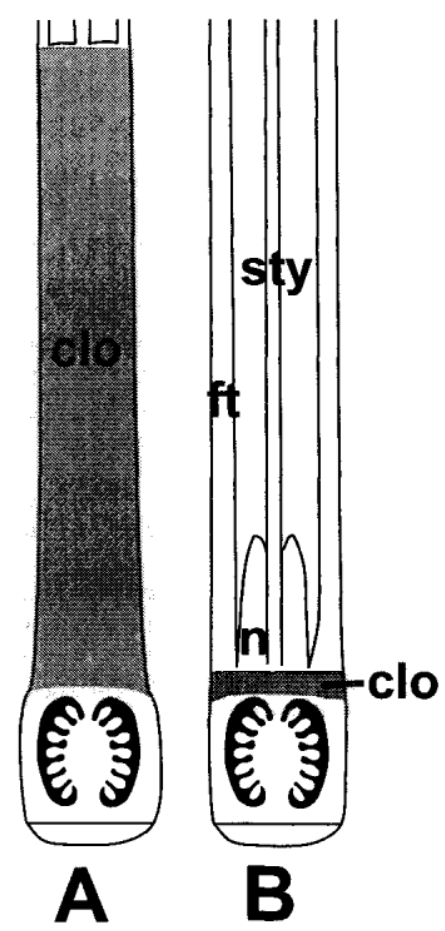

Fig. 25 Diagrams of ovary and closure of the ovary (clo) in relation to the floral tube $(f t)$. A, Orchidantha (Lowiaceae). B, Hedychium (Zingiberaceae). Note the extension of the closure in Orchidantha. Sepals not shown in either drawing. $n=$ epigynous nectaries; sty $=$ style. Drawings are not to scale.

indicate that the uni-/trilocular condition found in $S$. kunstleri evolved from a strictly trilocular condition.

In many families of the Zingiberales there is an extension of the ovary that lengthens the closure of the locules (fig. 25A). In some families (Strelitziaceae, Lowiaceae) this prolongation may function in protection of the ovary from pollinator damage (Kirchoff and Kunze 1995). This type of protection is important in species where the pollinators are vigorous in their search for nectar and could potentially damage the flowers (Frost and Frost 1981; Kress and Stone 1993; Kress et al. 1994). In the Zingiberaceae, at least part of this protective function may be assumed by the nectaries and floral tube (fig. 25B). The epigynous nectaries are borne on top of the ovary tightly wrapped in the floral tube (Holttum 1950; Rao 1963; S. W. Newman and B. K. Kirchoff, unpublished data). Pollinators probing for nectar would encounter the nectaries and the sides of the floral tube before contacting the ovary. This arrangement could restrict damage to nonessential parts of the flower while protecting the ovules.

\section{Flower Orientation}

At anthesis, the flowers of Scaphochlamys kunstleri have the same orientation as at initiation. This is similar to the situation in Hedychium gardnerianum but contrasts to that of $H$. coronarium, in which the mature flowers are resupinate (Kirchoff 1997). The flowers of $H$. coronarium are initiated with the same orientation as those of S. kunstleri (fig. 1) and H. gardnerianum but reorient during development. At anthesis, the labellum of $H$. coronarium is oriented toward the main inflorescence axis.

Flower Development

\section{Heterochrony}

The best way to evaluate changes in the timing of developmental events (heterochrony) is in the context of a specific phylogenetic hypothesis. I take the generic classification of the taxa discussed here to be such a hypothesis. The two species of Hedychium have a common ancestor. Scaphochlamys kunstleri is the sister group of the Glade that contains these species. The outgroup is the Costaceae.

Flower and inflorescence development are relatively similar in Scaphochlamys kunstleri, Hedychium gardnerianum, and $H$. coronarium (Kirchoff 1997). Differences in flower development among these species are seen mainly in the relative timing of developmental events (table 1 ).

The lack of an absolute time scale against which to judge development in these species means that I must use a relative time scale to compare events. I base this scale on specific stages in the development of an organ (or organ system) and use these stages as markers against which to judge the development of other organs. For instance, the stage at which the first and second, but not the third, sepals have initiated can be used as a marker against which to judge the formation of the ring primordium. In S. kunstleri and H. gardnerianum, the ring primordium is still in the process of forming at this stage, whereas in $H$. coronarium the ring primordium is already present (table 1). Similarly, I use the stage at which the common primordia are separating to investigate gynoecial initiation. This stage coincides with the initiation of the gynoecium in $S$. kunstleri, while gynoecial initiation in $H$. gardnerianum and $H$. coronarium occurs much later (table 1 ).

A comparison of developmental events shows that their relative timing varies among species, even over short periods. At the reference stage "obdeltoid primordium," each species is at a slightly different developmental stage (table 1). As development proceeds, similarities occur between $S$. kunstleri and $H$. gardnerianum (reference stages "two sepals initiated" and "separation of first common primordium") and between S. kunstleri and H. coronarium (reference stage "sepals fused laterally").

If development were a direct reflection of phylogeny, we would expect the species of Hedychium to be more similar to each other than to S. kunstleri at all stages of development. The fact that similarities cross generic lines indicates that other factors are at work. The early similarity between S. kunstleri and H. gardnerianum can be explained by an acceleration of floral development in $H$. coronarium (Kirchoff 1997). During the first three stages of development, the flowers of $H$. coronarium are ahead of those of $H$. gardner- 
Table 1 Differences in Floral Development among Scaphochlamys kunstleri, Hedychium gardnerianum, and H. coronarium

\begin{tabular}{|c|c|c|c|}
\hline Reference stage & $\begin{array}{c}\text { Comparison stage in } \\
\text { Scaphochlamys kunstleri }\end{array}$ & $\begin{array}{l}\text { Comparison stage in } \\
\text { Hedychium gardnerianum }\end{array}$ & $\begin{array}{l}\text { Comparison stage in } \\
\text { Hedychium coronarium }^{\mathrm{a}, \mathrm{b}}\end{array}$ \\
\hline Obdeltoid primoridium $\quad \ldots \ldots \ldots \ldots \ldots$ & Flattened floral apex (fig. 6) & Domed floral apex (fig. 15) & $\begin{array}{l}\text { Ring primordium forming (fig. } \\
\text { 35) }\end{array}$ \\
\hline Two sepals initiated $\ldots \ldots \ldots \ldots \ldots \ldots$ & $\begin{array}{l}\text { Ring primordium forming } \\
\text { (fig. 7) }\end{array}$ & $\begin{array}{l}\text { Ring primordium forming } \\
\text { (figs. 16, 17) }\end{array}$ & $\begin{array}{l}\text { Ring primordium present (fig. } \\
\text { 36) }\end{array}$ \\
\hline Sepals fused laterally $\ldots \ldots \ldots \ldots \ldots$ & $\begin{array}{l}\text { Ring primordium present } \\
\text { and common primordia } \\
\text { separating (figs. } 12,13 \text { ) }\end{array}$ & $\begin{array}{l}\text { Ring primordium present (fig. } \\
\text { 18) }\end{array}$ & $\begin{array}{l}\text { Ring primordium present } \\
\text { and common primordia } \\
\text { separating (figs. } 37,38 \text { ) }\end{array}$ \\
\hline Three common primordia present ... & $\begin{array}{l}\text { Posterior primordium larger } \\
\quad \text { (figs. } 9,11 \text { ) }\end{array}$ & $\begin{array}{r}\text { Primordia approximately } \\
\text { equal size (figs. 18, 19) }\end{array}$ & $\begin{array}{l}\text { Primordia approximately } \\
\text { equal size (fig. } 37 \text { ) }\end{array}$ \\
\hline $\begin{array}{l}\text { Separation of first common primor- } \\
\text { dium } \ldots \ldots \ldots \ldots \ldots \ldots\end{array}$ & Thecae formation (fig. 13) & Thecae formation (fig. 20) & No thecae present (fig. 38) \\
\hline Common primordia separation ....... & Gynoecial initiation (fig. 12) & $\begin{array}{l}\text { Floral cup empty (figs. } 20 \text {, } \\
\text { 21) }\end{array}$ & Floral cup empty (fig. 38) \\
\hline Thecae formation ... & $\begin{array}{l}\text { Stamen connective forms, be- } \\
\text { comes distinct at stigma ini- } \\
\text { tiation (fig. 15) }\end{array}$ & $\begin{array}{l}\text { Stamen connective forms and } \\
\text { becomes distinct (figs. } 20 \text {, } \\
21 \text { ) }\end{array}$ & $\begin{array}{l}\text { Stamen connective forms, be- } \\
\text { comes distinct only slightly } \\
\text { later than in } H \text {. gardner- } \\
\text { ianum (fig. } 39 \text { ) }\end{array}$ \\
\hline Floral cup triangular $\ldots \ldots \ldots \ldots \ldots$ & $\begin{array}{l}\text { Gynoecial initiation (figs. } 12 \text {, } \\
\text { 13) }\end{array}$ & $\begin{array}{l}\text { Common primordia separa- } \\
\text { tion (fig. 20) }\end{array}$ & $\begin{array}{l}\text { Common primordia separa- } \\
\text { tion (fig. 38) }\end{array}$ \\
\hline
\end{tabular}

Note. Bold entries show similar states.

a Figure citations refer to Kirchoff (1997).

b There is some variability in flower development in $H$. coronarium not represented in this table (B. K. Kirchoff, unpublished data).

ianum (Kirchoff 1997), which causes the flowers of $S$. kunstleri and $H$. gardnerianum to be more similar to each other at the stage "two sepals initiated" (table 1).

Another change in timing is the acceleration of reproductive development in S. kunstleri. Early in development, the portion of the ring primordium that forms the stamen enlarges precociously (figs. 9, 11). This accounts for Scaphochlamys's larger posterior primordium at the stage "three common primordia present." The gynoecium also forms much earlier in Scaphochlamys than in either species of Hedychium. It initiates at the beginning of common primordia separation (fig. 12). Precocious gynoecial development accounts for Scaphochlamys's unique character states at the stages "common primordia separation" and floral cup triangular" (table 1).

The similarity between $S$. kunstleri and $H$. coronarium at the stage "sepals fused laterally" is due to the relatively early "fusion" of the sepals in $H$. gardnerianum. This early "fusion" is also found in Costus scaber and may represent the primitive state in the Zingiberaceae (Kirchoff 1988b).

Relatively late formation of the thecae in H. coronarium leads to the absence of thecae at the stage "separation of first common primordium." This accounts for the similarity between 5: kunstleri and H. gardnerianum at this stage (table 1). Costus scaber shows an ever-later initiation of its thecae, which indicates that "late initiation" may be the primitive state.

The rate at which the thecae enlarge relative to the center connective determines the stage at which the connective forms and becomes distinct. In the two species of Hedychium this occurs at approximately the stage of "thecae formation" (table 1). Although the connective forms at the same stage in S. kunstleri, the thecae enlarge more slowly and the connective becomes distinct only at a later stage.

Few, if any, of the developmental changes described here can be directly related to mature flower structure. From the perspective of the mature flower, it seems to make little difference whether, at the stage when two sepals are initiated, the ring primordium is merely in the process of forming or is already present and symmetrical (table 1). However, since the developmental events described here and in Kirchoff (1997) are relatively stable, there must be some significance to the developmental differences between species. If flower development were always more similar between $H$. gardnerianum and $H$. coronarium, we could conclude that development is hierarchically arranged along taxonomic lines. Since this is not so, we are left with a case of developmental variation seemingly unrelated either to mature floral form or taxonomy. It appears that development is changing in a mosaic fashion. Early developmental events are accelerated in one species, whereas reproductive development is accelerated in another. In a prior study (Kirchoff 1983a), I found a similar lack of relation between taxonomy and the later stages of flower development (allometric growth), but in this case there was a clear correlation between development and mature floral form.

\section{Shape}

The first shape difference concerns the distinctness of the common primordia that separate to form the corolla and inner androecial members. There is an interspecific gradation in the degree of distinction between the common primordia and the ring primordium on which they are born. The common primordia of Hedychium coronarium are less distinct from their ring primordium than are those of $H$. gardnerianum (Kir- 
choff 1997, figs. 19, 37). The common primordia of Scaphochlamys kunstleri (fig. 10) are less distinct from the ring primordium than in either of these species of Hedychium.

The second difference in primordium shape is that the floral cup remains more open in $H$. gardnerianum than in $H$. coronarium or $S$. kunstleri. At the time of outer androecial initiation the floral cup of $H$. gardnerianum remains open (fig. 21 in Kirchoff 1997) while that of $H$. coronarium is occluded by the thecae and inner androecial members (fig. 39 in Kirchoff 1997). At this same stage the floral cup of S. kunstleri has been filled by the initiation of the gynoecium, which takes place at the stage of common primordia separation in this species.

\section{Sequence of Sepal Initiation}

In $S$. kunstleri there is a difference in the sequence of sepal initiation between the first and second flowers of a cincinnus (fig. 1). This difference is an indication that these two flowers are mirror images of each other. Thus, the second flower is not merely a rotated duplicate of the first but its mirror image. This relationship has more to do with morphological and developmental constraints on the sites of sepal initiation than with typological morphology. In both flowers, the initiation of the first sepal takes place in the region that is far from the area occupied by the preceding primordium. This is an expression of Hofmeister's (1868) axiom, which says that new primordia arise on an apex in positions that are farthest removed from the nearest existing primordia. In the first flower, this is the region of the flower primordium (approximately) opposite the secondary bract (figs. 1, 7). In the second flower, it is the region opposite the tertiary bract and far from the first flower (fig. 1).

It is also possible to explain the placement of the second sepal in the context of these developmental constraints. In the first flower, the posterior region of the flower develops before the anterior (fig. 5). Thus, the initiation of the second sepal in a posterior position can be explained by the greater maturity of this region of the flower primordium. The anterior side of the first flower is the last region to develop, and the last to initiate a sepal. In the second flower, the posterior side of the flower is adjacent to the newly formed tertiary bract and is, thus, unavailable for the initiation of the second sepal. This constraint places the second sepal in the posterior position, close to the insertion of the first flower.

Unfortunately, there are few data in the literature on the development of the second flower in normally constructed cincinni. This lack prevents comparisons between normally oriented and rotated second flowers. Based purely on the morphology of the cincinni, it is likely that there are similar constraints on the development of normally oriented second flowers (cf. figs. 1,2 ). If this is so, we are left with the question of how to account for the differing orientations in the two types of cincinni. They cannot be explained by different developmental constraints. To refer this question to the level of gene activation begs the real issue. Different spacial and/or temporal patterns of gene activation are most likely correlated with the different floral orientations, but we are still left with the questions of what causes the different patterns of gene activation in flowers with different orientations.

\section{Acknowledgments}

Portions of data collection for this article were carried out at Fairchild Tropical Garden, Miami, Fla. I thank Jack Fisher for his support and encouragement during this work and the staff of Fairchild Tropical Garden, who grew some of the plants used in this study. I also thank Rosemary Smith for supplying rhizomes of Scaphochlamys kunstleri on which this study was based. S. W. H. Newman prepared the paraffin and plastic sections and assisted with other technical aspects of the work. Alice Garmon and Catherine York printed the plates with the assistance of Daniel Smith. David Talbert and Mary Katherine Amos assisted in finding several citations, and Mark Schumacher translated Lestiboudois (1929). I also thank Paula Rudall and an unidentified reviewer for many helpful comments. Although I am grateful for everyone's help, the conclusions and opinions expressed in this article remain solely my responsibility. This article is based on work supported by the NSF under grants BSR-8307103 and BSR-880178 and by two research council grants from the University of North Carolina at Greensboro.

\section{LiteraturereCited}

Berlyn GP, JP Miksche 1976 Botanical microtechnique and cytochemistry. Iowa State University Press, Ames. 326 pp.

Bissing DR 1974 Haupt's gelatin adhesive mixed with formalin for affixing paraffin sections to slides. Stain Technol 49:116-117.

Brown WH 1938 The bearing of nectaries on the phylogeny of flowering plants. Proc Am Phil Soc 79:549-595.

Carlquist S 1982 The use of ethylenediamine in softening hard plant structures for paraffin sectioning. Stain Technol 57:311-317.

Charlton WA, AD Macdonald, U Posluszny, CP Wilkins 1989 Additions to the technique of epi-illumination light microscopy for the study of floral and vegetative apices. Can J Bot 67:1739-1743.

Costerus JC 1915 Das Labellum und das Diagram der Zingiberaceen. Ann Jard Bot Buitenzog II 14:95-108.

Dahlgren RMT, FN Rasmussen 1983 Monocotyledon evolution: characters and phylogenetic estimation. Evol Biol 16:255-395.
Eichler AW 1875 Blüthendiagramme construirt und erläutert. 2 vols. Engelmann, Leipzig. 1884 Über den blüthenbau der Zingiberaceen. Sitzungsber K Preuss Akad Wiss 26:585-600.

Endress P 1994 Diversity and evolutionary biology of tropical flowers. Cambridge University Press, Cambridge. 511 pp.

Frost SK, PGH Frost 1981 Sunbird pollination of Strelitzia nicolai. Oecologia 49:379-384.

Hofmeister W 1868 Allgemeine Morphologie der Gewächse. Engelmann, Leipzig.

Holttum RE 1950 The Zingiberaceae of the Malay peninsula. Gard Bull Sing 13:1-249.

Johansen DA 1940 Plant microtechnique. McGraw-Hill, New York. $523 \mathrm{pp}$.

Kirchoff BK 1983a Allometric growth of the flowers of five genera 
of the Marantaceae and of Canna (Cannaceae). Bot Gaz 144:110118.

1983 b Floral organogenesis in five genera of the Maran-

taceae and in Canna (Cannaceae). Am J Bot 70:508-523.

1988 a Floral ontogeny and evolution in the ginger group of the Zingiberales. Pages 45-56 in P Leins, SC Tucker, PK Endress, eds. Aspects of floral development. Cramer, Berlin.

1988b Inflorescence and flower development in Costus scaber (Costaceae). Can J Bot 62:339-345.

1997 Inflorescence and flower development in the Hedy-

chieae (Zingiberaceae): Hedychium. Can J Bot 75:518-594.

Kirchoff BK, H Kunze 1995 Floral development of Orchidantha maxillarioides (Lowiaceae). Int J Plant Sci 156:159-171.

Klaauw CJ van der 1966 Introduction to the philosophic backgrounds and prospects of the supraspecific comparative anatomy of conservative characters in the adult stages of conservative elements of vertebrata with an enumeration of many examples. Verh K Ned Akad Wet Afd Natuurk De Tweede Sect 57:1-196.

Kodak 1983 Kodak technical pan film 2415. Kodak Pamphlet no. P-255. Eastman Kodak, Rochester, N.Y.

Kress WJ 1990 The phylogeny and classification of the Zingiberales. Ann Mo Bot Gard 77:698-721.

__ 1995 Phylogeny of the Zingiberanae: morphology and mol-

ecules. Pages 443-460 in PJ Rudall, PJ Cribb, DF Cutler, CJ Humphries, eds. Monocotyledons: systematics and evolution. Royal Botanic Gardens, Kew.

Kress WJ, GE Schatz, M Andrianifahanana, HS Morland 1994 Pollination of Ravenala madagascariensis (Strelitziaceae) by lemurs in Madagascar: evidence for an archaic coevolutionary system? Am J Bot 81:542-551.

Kress WJ, DE Stone 1993 Morphology and floral biology of Phenakospermum (Strelitziaceae), an arborescent herb of the Neotropics. Biotropica 25:290-300.

Kunze H 1984 Vergleichende Studien an Cannaceen- und Marantaceen-blüten. Flora 175:301-318.

1985 Die Infloreszenzen der Marantaceen und ihr Zusam-

menhang mit dem Typus der Zingiberales-Synfloreszenz. Beitr Biol Pflanz 60:93-140.

1986 Infloreszenz- und Blütenmorphologie von Orchidan-

tha maxillarioides (Ridl.) K. Schumn. (Lowiaceae). Beitr Biol Pflanz 61:221-234.

Lestiboudois T 1829 Notice sur le genre Hedychium de la famille des Musacées (Balisiers et Bananiers). Ann Sci Nat Prem Ser 17: 113-139.

Newman SW, BK Kirchoff 1992 Ovary structure in the Costaceae (Zingiberales). Int J Plant Sci 153:471-487.
Pai RM 1963 The floral anatomy of Canna indica L. Bull Bot Soc Coll Sci Nagpur 4:45-53.

Pai RM, VD Tilak 1965 Septal nectaries in the Scitamineae. J Biol Sci $8: 1-3$.

Posluszny U, MG Scott, R Sattler 1980 Revisions in the technique of epi-illumination light microscopy for the study of floral and vegetative apices. Can J Bot 58:2491-2494.

Rao VS 1963 The epigynous glands of Zingiberaceae. New Phytol 62:342-349.

Rao VS, K Gupte 1961 The floral anatomy of some Scitamineae. Part IV. J Univ Bombay Sect B 29:134-150.

Rao VS, H Karnik, K Gupte 1954 The floral anatomy of some Scitamineae. Part I. J Ind Bot Soc 33:118-147.

Rao VS, RM Pai 1959 The floral anatomy of some Scitamineae. Part II. J Univ Bombay 28:82-114. 1960 The floral anatomy of some Scitamineae III. J Univ

Bombay 28:1-19.

Sattler R 1968 A technique for the study of floral development. Can J Bot 46:720-722.

1984 Homology: a continuing challenge. Syst Bot 9:382-

394.

Schachner J 1924 Beiträge zur Kenntnis der Blüten- und Samenentwicklung der Scitamineen. Flora 117:16-40.

Schumann K 1904 Zingiberaceae. In HGA Engler, ed. Das Pflanzenreich IV, 46. Engelmann, Leipzig.

Smets EF, EM Cresens 1988 Types of floral nectaries and the concepts "character" and "character-state": a reconsideration. Acta Bot Neerl 37:121-128.

Smith RM 1981 Zingiberaceae, synotpic keys to the tribes Zingibereae, Globbeae, Hedychieae, Alpineae (in part). Royal Botanical Garden of Edinburgh, Department of Publications Series number 2, Edinburgh.

Tilak VD, RM Pai 1970 Studies in the floral morphology of the Marantaceae. III. Vascular anatomy of the flower in some species of the genus Calathea. Marathwada Univ J Sci 9:31-41.

Troll W 1928 Organisation und Gestalt im Bereich der Blüte. Springer, Berlin. 413 pp.

__ 1964 Die Infloreszenzen: Typologie und Stellung im Auf-

bau des Vegetationskörpers. Vol 1. Gustav Fischer, Stuttgart. 615

PP.

Tucker SC 1984 Origin of symmetry in flowers. Pages 351-395 in RA White, WC Dickison, eds. Contemporary problems in plant anatomy. Academic, Orlando, Fla.

von Baer KE 1828 Entwicklungsgeschiche der Thiere: Bobachtung und Reflexion. Bonträger, Konigsberg. 264 pp.

Weberling F 1989 Morphology of flowers and inflorescences. Cambridge University Press, Cambridge. 405 pp. 